\title{
IMT Skills of the Pre-service Teachers in Cebu City
}

\author{
Helen B. Boholano \\ College of Teacher Education, Cebu Normal University
}

\begin{tabular}{l} 
Article Info \\
\hline Article history: \\
Received Jul 9, 2018 \\
Revised Jul 31, 2018 \\
Accepted Aug 26, 2018 \\
\hline Keyword: \\
IMT \\
modern technology \\
21st century skills \\
instructional strategies
\end{tabular}

\begin{abstract}
Information, media and technology is an essential skill in the 21 st century. The development of the country relies on the people. The preservice teachers are task to mold the 21 st century learners. The purpose of this study is to investigate and analyze the information, media and technology skills in the 21 st century of the preservice teachers in the different Higher Education Institutions (HEIs) in Cebu City. Findings revealed that the preservice teachers possessed very IMT good skills. There are three themes formulated regarding the effects of new digital technologies in the 21st century instruction. Making taking and learning more convenient with the use of technology, the 21 st century role of modern technology in teaching and learning and using technology as tool in research are essential in the 21st century undertakings. Thus, ICTs have been very useful in the teachinglearning process and it has been the modernize way of education which caught the interest of everybody. The effective use of technology enables the preservice teachers to facilitate and adjust their instructional strategies to optimize students' learning.
\end{abstract}

Copyright $\left({ }_{0} 2018\right.$ Institute of Advanced Engineering and Science. All rights reserved.

\section{Corresponding Author:}

Helen B. Boholano,

College of Teacher Education,

Cebu Normal University,

Osmena Blvd., Cebu City, Philippines

Email: hibihag08@gmail.com

\section{INTRODUCTION}

Mastery of core subjects and $21^{\text {st }}$ century themes as well as understanding of academic content at much higher levels by weaving $21^{\text {st }}$ century interdisciplinary themes into core subjects is essential for preservice teachers in the $21^{\text {st }}$ century. Progress and developments in society and economy require that educational systems equip young people with new skills and competencies, which allow them to benefit from the emerging new forms of socialization, globalization and internationalization which can contribute actively to economic development under a system where the main asset is knowledge. There is an "emergence of very sophisticated information and communications technologies in the $21^{\text {st }}$ century that is one major difference that $20^{\text {th }}$ century" $[1]$.

Generation $\mathrm{Z}$ teachers are already experiencing the new forms of socialization and social capital acquisition that Information, Communication and Technology (ICT) developments are contributing [2] to the development of the educational system. [1] disclose that "Complex communication requires the exchange of vast amounts of verbal and nonverbal information and this information flow is constantly adjusted as the communication evolves unpredictably". Information and Communication Technology (ICT) can provide more flexible and effective ways for professional development for students, teachers and administrators and connect them to the global community.

It is said that "computers are increasingly widespread, influencing many aspects of our social and work lives, as well as many of our leisure activities" [3]. Information, Media and Technology skills is as essential as other $21^{\text {st }}$ century skills in the development of lesson designs and instructional materials by the preservice teachers for proper utilization. Preservice teachers in Cebu City must be equipped with these skills for theme to compete with other preservice teachers in the world. There are many advantages of using an 
integrating technology in the classroom, especially as students become increasingly digitally literate. The use of technology allows teachers to engage and motivate students in new and sophisticated ways such as taking students on a virtual field trip and other simulated activities. Thus, "the success of any initiatives to implement technology in an educational program depends strongly upon the support and attitudes of teachers involved" [4]. Thus, this study will investigate the $21^{\text {st }}$ century skills possessed by the preservice teachers in terms of IMT skills.

There are many studies related to ICT literacy and IMT skills of the teachers in basic education. Information and media literacy, critical thinking and communication are skills that belong to effective communication. [4] proposed that "if teachers believed or perceived computers not to be fulfilling their own or their students' needs, they are likely to resist any attempts to introduce technology into their teaching and learning". "Initiatives on the teaching and assessment of 21 st century skills originate in the widely-held belief shared by several interested groups - teachers, educational researchers, policy makers" [2]

It is noted that the importance of ICT is quite evidence from the educational perspectives through the chalkboard, textbooks, radio/television and file have been used for educational purposes over the years, none has quite impacted program on the educational process like the computer [5]. Technology is used to sustain the existing curricula rather than serve as a catalyst for change [6]. Technology is often used as the generic term to encompass all the technologies people develop and use in their lives.

ICT is a powerful tool in the hands of confident, capable and creative general studies teachers can greatly enhance many teaching and learning situation [5]. According to [2], the " $21^{\text {st }}$ Century School Initiative in Canada has recently begun and has as objectives to define, promote and focus upon 21 st century skills; create innovative learning environments; and to provide ubiquitous access to technology in classrooms". It is said that teacher is key to effective implementation of the use of computers in the educational system and given that teachers have tremendous potential to transmit beliefs and values to students, it is important to understand the biases and stereotypes that teachers may hold about the use of computers and the factors that act as facilitators to teachers' positive computer usage [3]. $21^{\text {st }}$ century info fluency defines information literacy as "the ability to locate, evaluate and use information." The ability of information consumers to make educated, smart, information assessments requires a special kind of literacy termed Information Literacy [7]. In the same study, literacy acts was discussed as a filter: it identifies false, irrelevant, or biased information, and avoids its penetration into the learner's cognition.

It is clearly stated in [2] that "the information explosion triggered by ICT requires new skills for accessing, evaluating, and organizing information in digital environments". According to [8] that ICT relevant literacies, such as ICT capability, digital literacy, IT fluency, and ICT literacy were considered intellectual/cognitive proficiencies and critical competencies as inseparable parts of the nature of ICT education.

The "visual communication in relation to IMT skills as an interactive environment is constructed of multi-layered and ambiguous symbols systems that are both syntactically and semantically dense" [9]. In visual communication, the syntactic elements are those visual characters that are used, while the semantic elements relates to the correlation, compliance and connection between the visual symbols that serve to deposit meaning into visual metaphors used to communicate.

Using sophisticated telecommunications, knowledge networking by teachers in online virtual communities of practice using advanced tools to solve real world problems is practical and sustainable for many curricular topics [10]. It is noted "that schools can only encourage information and communication technology (ICT) use, and that any actual take-up depends largely on teachers' skills and capabilities" [11]. There are characteristics of new technologies with the skills and abilities 'Information Age children' need in order to function effectively as productive and happy citizens [12].

"The phenomenal impact of new technologies on all aspects of life in modern societies is one of the factors that led to the need for the teaching of new skills at schools" [2]. In the same study, it discusses that ICT has a crucial role in all relevant debates, not merely because it implies a new set of skills to be learnt by teachers and students, but because of its potential impact on the development of other skills and competencies as well as on pedagogical and assessment practices.

This study would investigate the IMT skills possessed by the preservice teachers in HEIs in Cebu City. It is believed that ICT integration is the combination of ICT technology into different subject areas the basic education curriculum to enhance learning.

\section{OBJECTIVES OF THE STUDY}

The purpose of this study is to investigate and analyze the information, media and technology skills in the $21^{\text {st }}$ century of the preservice teachers in the different Higher Education Institutions (HEIs) in Cebu City. Specifically, it will answer the following objectives: 
1. Determine the preservice teachers IMT skills;

2. Identify the effects of new digital technologies in the $21^{\text {st }}$ century instruction; and

3. Determine the strategies for using ICTs to change pedagogical practices in teaching and learning

\section{RESEARCH METHOD}

The study utilized mixed methods of qualitative and quantitative research for collection of proper data. Standardized survey questionnaires were distributed to the participants of this study. All participants were briefed on the purpose of this study and their rights not to participate in the study. The table below presents the participants of the study:

Table 1. Participants of the Study

\begin{tabular}{cccc}
\hline School & No. of graduates & No. of Participants & $\%$ \\
\hline University A & 44 & 8 & $2 \%$ \\
University B & 38 & 8 & $2 \%$ \\
University C & 112 & 40 & $11 \%$ \\
University D & 160 & 32 & $9 \%$ \\
University E & 894 & 241 & $66 \%$ \\
University F & 190 & 38 & $10 \%$ \\
TOTAL & 1,438 & 367 & $100 \%$ \\
\hline
\end{tabular}

Focus group discussion was conducted after the data collection to validate its entry. The study will be conducted in 6 HEIs in Cebu City. The study was conducted from June 2016 - March 2017. The data gathered were tabulated, analyzed and interpreted.

After tabulating the results of the survey, the researcher will get the $30 \%$ high IMT skills and $30 \%$ low IMT skills. The study used discriminant analysis to determine the characteristics of goof IMT skills and low IMT skills of the pre-service teachers. Discriminant analysis is a classification problem, where two or more groups or clusters or populations are known a priori and one or more new observations are classified into one of the known populations based on the measured characteristics. The purpose of discriminant analysis can be to find one or more of the following: a mathematical rule for guessing to which class an observation belongs, a set of linear combinations of the quantitative variables that best reveals the differences among the classes, or a subset of the quantitative variables that best reveals the differences among the classes.

\section{RESULTS AND ANALYSIS}

The questionnaires were retrieved by the researcher and the results were interpreted. The table below presents the Pre-service teachers' level of skills along information, media and technology.

The Pre-Service Teachers have very good knowledge of the use of technology as revealed in Table 2. They have excellent knowledge on basic MS word application and electronic mail applications and accessing and evaluating resources. One of the respondents said: "We had ICT training in our university and for us it is very important for we can be better than other teacher applicants in the future". These are supported by [13] "report that equipping students with ICT literacy that meets the demands of the 21st century is very important; because of this various training and ICT courses were implemented to in-service teachers and pre-service teachers".

Moreover, the Preservice Teachers are also excellent in some activities using spreadsheets. One of the Pre-service teachers said, "We need to learn $21^{\text {st }}$ century skills like ICT because we are future teachers". This implies that preservice teachers are technology literate. Computer literacy has become a key factor for both occupational and personal successes as more tasks involve human-computer interaction [4]. This is verified by one of the respondents who said that "computers and other ICT equipment are available in our classroom". This implies that the university supported one of the $21^{\text {st }}$ century skills. Findings revealed that the supports in terms of skills training, information or materials available as well as administrative support is an important factor in the use of instructional technologies in teaching and learning [4]. Thus, the preservice teachers claimed that the school heads are very supportive in giving them trainings and workshop in line with technology. But it is noting that only basic skills such as MS Word, Spreadsheets, PowerPoint, and basic usage of Publisher were introduced.

One of the Preservice teachers said "It made the instruction in school easier. It provide more information and the uses of Words, Documents, PowerPoint, Spreadsheet are very reliable. More resources

IJERE Vol. 7, No. 3, September 2018 : 212 - 220 
for researchers that can be found in different sites in the internet". This implies that Information is very important and it can change the lives of individual especially the status of students in school. The more information teachers have, the more he/she can interact to the students and mentors and through this, the preservice teacher become a better and effective teacher.

Table 2. The Level of Pre-Service Teachers' Knowledge of IMT

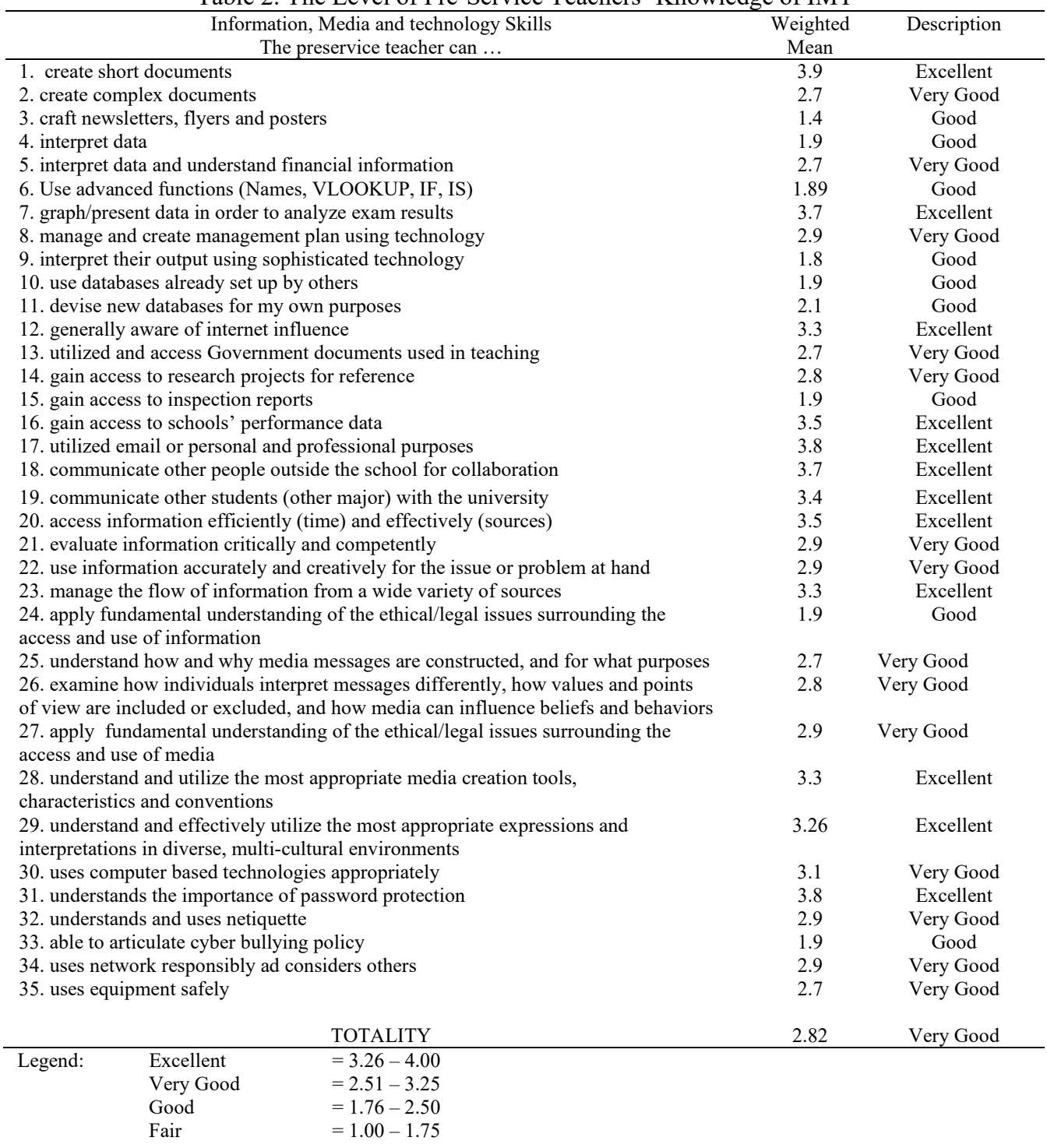

$21^{\text {st }}$ century learners are technology-oriented. Teachers should be not only aware to the basic technology but also obtain mastery skills regards of this invention of schools because these made the instruction easier and convenient. This is verified by one of the preservice teachers, "We are more in the higher pace of generation, $21^{\text {st }}$ century greatly have a great impact not just education but also to all the work that a society need, because of easier, faster and most convenient way in doing a job or has a great purposes ads". This means that there is widespread belief that ICT can and will empower teacher and learners, transforming teaching and learning processes from the being highly teacher-dominated to student-centered and that this transformation will result in increased learning gains for students, creating and allowing for opportunities for learners to develop their creativity, problem-solving abilities, informational reason skills and other higher-order thinking skills. 
With all these, the preservice teachers also have difficulties and weaknesses of IMT skills. They have not experienced creating tables, report and the like with the use of Data Base Management System. It is very evident in this study because they are only good in such applications.

The preservice teachers also need training on ethical and legal issues of technology. Even if the preservice teachers are computer literate there is no proper training on copyright issues, ethical and legal consideration in the use of technology. One of the respondents said: "I know some rules in posting to social media as well as some ethical consideration in copying and pasting but there is no proper training on that topic". This implies that they need training on legal and ethical issues in use of technology. Even if they don't have proper training, they are creative and innovative in reading articles related on this matter. It is said that to prepare for success in the workplace, preservice teachers need to become independent, and critical thinkers.

Table 3. Experience of the Preservice Teachers in the use of IMT

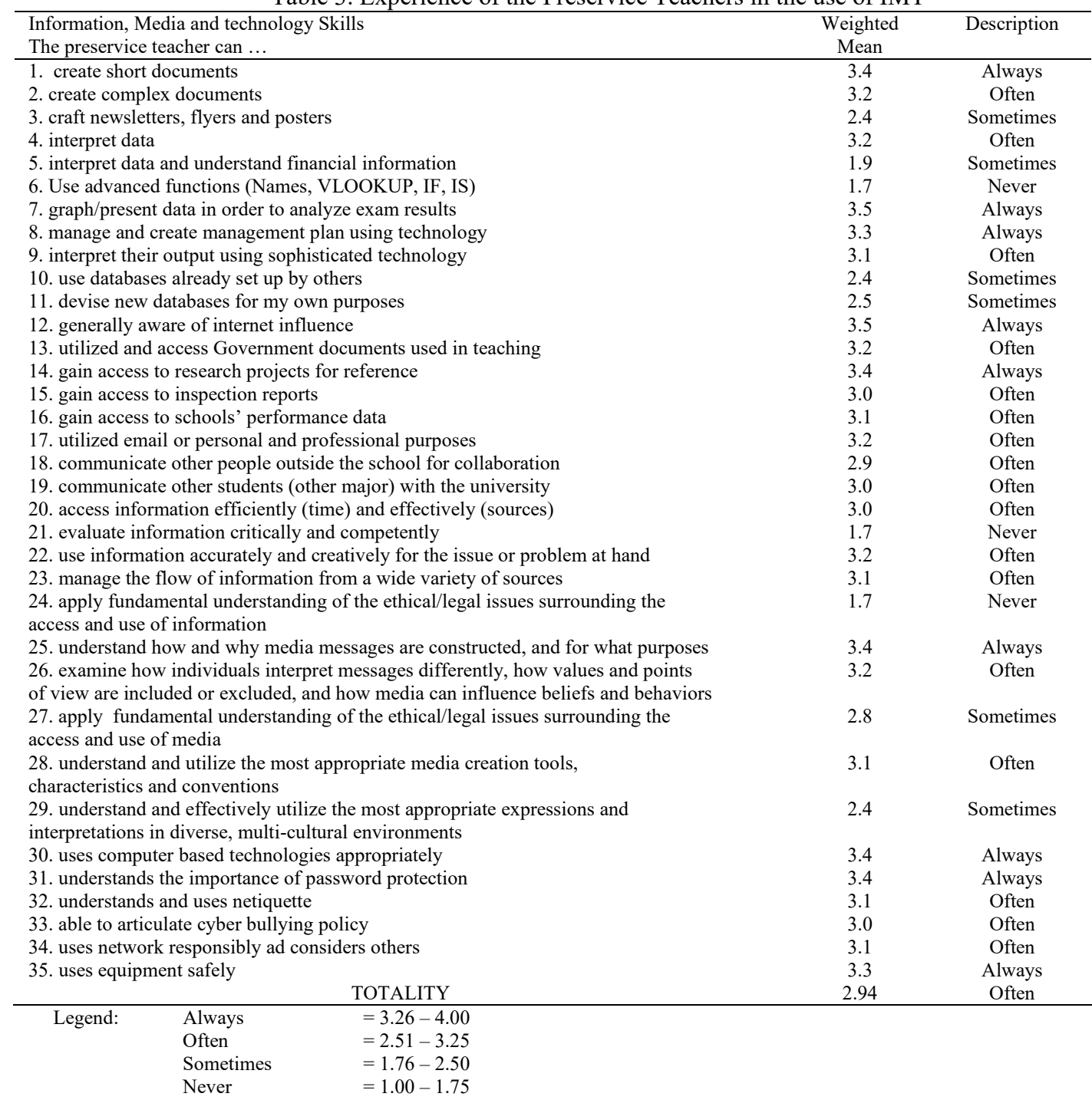

The challenges of the 21 st century is to look into the skills both students and teachers. The teacher must be equipped with these skills so that the students will also learn from them. Findings also showed that "the ability to work with data, such as: analyzing information, making inferences from data, finding trends, and using data to support claims are considered to be one of the main skills that students need to be literate in today's information age, and to equip them with everything needed for the world beyond the classroom, due

IJERE Vol. 7, No. 3, September 2018: $212-220$ 
to the growing use of visual representation of data in the form of graphs and tables in different aspects of life [14]." Table 3 reveals that the preservice teachers are always using excel and graphing the test results and other data especially in research activities. It has a weighted mean of 3.5 which is the highest skills of all the IMT skills presented in Tale 3. It is also the most commonly used by the preservice teachers together with the awareness of internet influence.

Another very commonly used and utilized by the preservice teachers are creating simple documents. Aside from that, the preservice teachers are also using computer appropriately with the weighted man of 3.4. The preservice teachers are also preparing to deal with policy regulations governing appropriate uses of the computer and Internet in school. One of the respondents said: "We usually used PC especially in preparing our visual aids and collaborating our students". This implies that the preservice teachers spent most of their time on the computer doing school-related works especially preparing the instructional materials, using email, and web browsing. The data indicated that the preservice teachers had experience with the computer doing simple and complex task and using Internet especially in doing research.

On the other hand, the preservice teachers are not used to apply fundamental understanding of the ethical/legal issues surrounding the access and use of information for it has a weighted mean of 1.7 (never). It is also pointed that "teachers need not only to understand the policies but also to have an awareness of students' beliefs, so that they can offer students more than a set of policy regulations like Ethical issues are complex [and] a list of rules is not adequate to help enhance a student's understanding”[15].

Thus, the preservice teachers are utilizing information, media and technology in teaching and learning. They are using computer almost every day for school activities and other requirements.

\section{Effects of new digital technologies in the $21^{\text {st }}$ century instruction}

This part of the research will provide the results and discussion about the different themes gathered by the research from the Focus Group Discussion (FGD) and from the interview questionnaire. From the responses of the preservice teachers, the following themes had been formulated:

Theme 1: Making taking and learning more convenient with the use of technology

Theme 2: The $21^{\text {st }}$ century role of modern technology in teaching and learning

Theme 3: Using technology as tool in research

\section{Making taking and learning more convenient with the use of technology}

It has a very big impact especially in $21^{\text {st }}$ century and students are more exposed to media and computers. So, not to be left behind, student and teacher should adjust and adapt these new inventions. One of the preservice teachers said:

"The impact of information media and technology literacy instruction in school is that it makes the instruction convenient especially if there is need for the remedial classes or additional assignment or activity. And also information media help to widen the knowledge of the student."

This implies that the learning acquired by using this tool is more efficient especially in the $21^{\text {st }}$ century world. Using media and technology is very applicable and more modern and gives more interesting activities for the learners. It is said that the impact of information, media and technology literacy instruction in schools is that it makes things easier and faster. It gives comfort to the teachers for they will not keep on writing on the board ad on manila papers, they just have to prepare PowerPoint presentation and the students will have to take down the important notes that are being discussed by the teacher. Another preservice teacher said:

"If the pre-service teachers are literate when it comes to information, media and literacy,

then it would be easier for them to apply what they have learned and to have beautiful outcomes with great quality most especially in doing responsibility as pre-service teachers"

Thus, the preservice teachers consider ICT as a teaching tool in the $21^{\text {st }}$ century. Aside from that it makes learning more engaging. It is really a great aid for teachers and student doing different task in school. It makes teaching process more meaningful. IMT provides great impact in school instruction. Aside from making things easier or better it provides learners accurate learning age $21^{\text {st }}$ century.

Another preservice teacher reveals that the use of technology makes teaching and learning faster and convenient. As quoted "Information, media and technology gives a great impact in schools instruction because we are now on $21^{\text {st }}$ century people now a day are dependent in technologies. And technology gives us access to everything like research, our reports news, access to government and everything. It makes our day by day easier." IMT improved student achievement and motivation. It provides the learner with quick and easy access to different sections of instructional materials than using printed materials. It helps the student and teachers to make work easier and faster and to make more enough sources of information. 
The impact of information, media and technology literacy instruction in schools also the students can easily access the information through the use of technology.

\section{The $21^{\text {st }}$ century role of modern technology in teaching and learning}

Teaching and learning in the $21^{\text {st }}$ Century requires tremendous preparation and innovation of the teachers. It enables the preservice teachers globally competitive. "The $21^{\text {st }}$ century is considered as the age of information and the school is having education of their banner, therefore, in order to update and go with the trend in education we must include ICT in our schools. If we are equipped with these skills, we can work easily on the working world", as mention by one of the respondents. According to [16] "contemporary ICTs are able to provide strong support for all these requirements and there are now many outstanding examples of world class settings for competency and performance-based curricula that make sound use of the affordances of these technologies". Thus, ICT enables the students to be technologically-oriented, globally competitive and a wide-ranged learner. For the students, it can access information form a whole world of diverse knowledge and ideas. Another preservice teacher said:

"It helps through giving immediate and immediate and accurate information and it is also

used to contract solid information to students and it catches attention."

This implies that the internet will provide information needed by the preservice teachers. Technology is influencing and supporting what is being taught and learned in schools for it also support changes to the way students are learning in this era. In [16], he cited that "technology has the capacity to promote and encourage the transformation of education from a very teacher directed enterprise to one which supports more student-centered models." ICT applications provide many options and choices that will make the preservice teachers innovative and creative.

\section{Using technology as tool in research}

The information media and technology literacy instruction help the students specifically in attaining new information, such as researching in order to gain more knowledge on the different lessons that we encounter every day. Knowing things about this instruction also teaches them on how to use media or technology well. One of the preservice teachers said:

"Being literate in information media and technology in school can help lighten the works to be done for the teachers, teachers and other workers who needs technology. For the teachers it helps them deliver their discussion well and they are able to show examples through PowerPoint, videos, picture and etc. for us students, we can access well or do things easily tasked assigned by the teachers. And for others, it can help them have smooth flow of their works. Besides ICT allow to do our research in a better way".

This means that ICT enable preservice teachers to do research. But on the other hand, technology has also a disadvantage. The influx of technology brought a great impact to the instruction of the school since the teachers and students are dependent on technology. Students browse the internet instead of book that would consider the internet as the most reliable source which could to plagiarism. Teachers rely on laptops and social media to convey their lesson.

Information, media and technology literacy allow student to have free access on wide of knowledge. In this way, students have wide opportunities of learning. However, it also bring negative impact such as acquiring hoax information and laziness to seek information

\section{Strategies for using ICTs to change pedagogical practices in teaching and learning}

The most relevant strategies to change pedagogical practices in teaching and learning for the needs of the student and school facilities. A concrete example of strategies using ICT affecting to the pedagogical practices in teaching and learning is when the teachers use projectors and gadgets in discussing their lesson. It can also be seen from the students who as well interact to the class discussion through the use of social Medias and technology. One of the preservice teachers said: "It is that specific uses of ICT can have positive effects on student achievement when ICT are used appropriately to complement teachers' existing pedagogical philosophies. ICT are used in education in two general way; to support existing traditional pedagogical practices as well as to enable more learner centric constructivist learning models, research form different countries suggest that both are useful, but that ICT are most effective when they help to enable learner-centric pedagogies." This means relevant strategies for using to change pedagogical practices in teaching and learning are utilizing the ICT tools using he PCs. Though not all school provide ICTs subject or computer laboratories, it is good these tools to achieve more modern and globally competent learners.

IJERE Vol. 7, No. 3, September 2018: $212-220$ 


\section{CONCLUSION}

From the findings revealed in the study, it is concluded that Information, media and technology literacy is needed in the $21^{\text {st }}$ century teaching and learning. ICTs have been very useful in the teachinglearning process and it has been the modernize way of education which caught the interest of everybody. The effective use of technology enables the preservice teachers to facilitate and adjust their instructional strategies to optimize students' learning.

\section{ACKNOWLEDGEMENTS}

The author would like to acknowledge the universities in Cebu City who responded this research endeavor and to Cebu Normal University who initiated this activity.

\section{REFERENCES}

[1] Dede, C. Comparing frameworks for 21st century skills. 21st century skills: Rethinking how students learn, 20, 2010; 51-76.

[2] Ananiadou, K., \& Claro, M. 21st century skills and competences for new millennium learners in OECD countries. 2009.

[3] Teo, T. (2008). Pre-service teachers' attitudes towards computer use: A Singapore survey. Australasian Journal of Educational Technology, January 2008

[4] Teo, T., Lee, C. B., \& Chai, C. S. (2008). Understanding pre-service teachers' computer attitudes: applying and extending the technology acceptance model. Journal of computer assisted learning, 24(2), 128-143.

[5] Umunadi, K. (2011). Perception of Technical Education Students on the Role of ICT in General Studies Programme (GSP) In University Education. International Journal of Academic Research in Business and Social Sciences October 2011.

[6] Moersch, C. (1995). Levels of technology implementation (LoTi): A framework for measuring classroom technology use. Learning and Leading with technology, 23, 40-40.

[7] Jones, B. \& Flannigan, S. (n.d.) Connecting the Digital Dots: Literacy of the 21st Century.

[8] Drenoyianni, H. (2004). Designing and Implementing a Project-Based ICT Course in a Teacher Education Setting: Rewards and Pitfalls. Education and Information Technologies 9:4, 387-404, 2004.

[9] Bamford, A. (2001). The Grammar of Visual Literacy within the World of Interactive Media. Paper presented at the Education Research Network Conference on Learning, Spetses, Greece, and July 4-8.

[10] Dede, C. (2000). Emerging influences of information technology on school curriculum. Journal of Curriculum Studies, 32(2), 281-303.

[11] Angeli, C., \& Valanides, N. (2005). Preservice elementary teachers as information and communication technology designers: An instructional systems design model based on an expanded view of pedagogical content knowledge. Journal of Computer Assisted Learning, 21(4), 292-302.

[12] Andersen, N. (2002). New Media and New Media Literacy: The horizon has become the landscape - new media are here. p. $30-35$.

[13] Mahmud, R., \& Ismail, M. A. (2010). Impact of training and experience in using ICT on in-service teachers' basic ICT literacy. Malaysian Journal of Educational Technology, 10(2), 5-10.

[14] Gheith, E. and Aljaberi, N. (2015). Pre-Service Classroom Teachers' Attitudes toward Graphs and Their Ability to Read and Interpret Them. International Journal of Humanities and Social Science. Retrieved from http://www.ijhssnet.com/journals/Vol_5_No_7_July_2015/14.pdf on March 31, 2017.

[15] Kafai, Y., Nixon, A., and Burnam, B. (2007). Digital Dilemmas: How Elementary Preservice Teachers Reason about Students' Appropriate Computer and Internet Use. Jl. of Technology and Teacher Education (2007) 15(3), 409-424. Retrieved from https://www2.gse.upenn.edu/c4ls/sites/gse.upenn.edu.c4ls/files/pdfs/JTTE_Kafai.pdf on March 31, 2017.

[16] Oliver, R. (2002). The role of ICT in higher education for the 21 st century: ICT as a change agent for education. Retrieved April, 14, 2007. 


\section{BIBLIOGRAPHY OF AUTHORS}

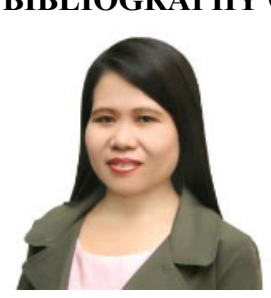

HELEN B. BOHOLANO, LIB, Ed. D. is a Full Professor of Cebu Normal University. She earned her doctorate degree in Administration and Supervision (2007), Master Arts in Education major in Administration and Supervision (2003- Mandaue City Scholar), Bachelor of Laws (2002) and Bachelor in Secondary Education major in Mathematics (1994-Magna Cum Laude \& Mandaue City Scholar) from the University of the Visayas, Cebu City. She also finished her Master of Arts in Education major in Special Education from Cebu Technological University in 2009. She has several researches published in an international referred journal as well as presented in Malaysia, Thailand, Hongkong, Vietnam, Australia and the Philippines. She authored books in Assessment of Student Learning, Educational Technology, Field Study and Quantitative Research. 